\title{
BUJSS
}

9/1 (2016), 173-186

\section{RISE OF NEO-POPULISM AND THE DECLINE OF EUROPEAN AGENDA IN TURKEY}

\begin{abstract}
Akif Bahadır KAYNAK
ABSTRACT

Turkey's adhesion process into EU brought with it an economic reform agenda based on establishment of liberal institutions and termination of populist policy making. Despite major achievements at its early years, consolidation of power by the ruling party induced a partial reversal of reform programs. Under AKP rule, Turkey's economic model started to rely more heavily on domestic consumption that was boosted with the help of global liquidity glut. The new economic model caused a setback from the liberal settings imposed after the 2001 crisis as independent institutions lost their autonomy and the Executive extended its all-encompassing power deeper into economic and social life. EU membership was supposed to reduce clientalist practices that had for long dominated political life but when this prospect was postponed at best, internal dynamics failed to support the liberal political and economic agenda. The rule of law and a non-partisan approach in provision of public goods that are required in order to create a healthy market economy were easily dismissed for political motivations. Populist policies expanded and consolidated the voter base of the ruling party. We aim to explain the process and dynamics of the new horizons of policy making in Turkey.
\end{abstract}

Keywords: rent-seeking, neo-populism, EU, Turkey, AKP

\section{TÜRKIYYE'DE YENİ POPÜLIZM'İN YÜKSELIŞİ VE AVRUPA GÜNDEMININN GERÍLEMESI \\ ÖZ}

Türkiye'nin AB'ye üyelik süreci beraberinde liberal kurumların ihdasına ve popülist politikaların sona erdirilmesine yönelik bir reform süreci getirdi. İlk yıllardaki başarılarına karşın, iktidar partisinin gücünü sağlamlaştırmasıyla bu reform sürecinde bir geri dönüş yaşandı. AKP yönetiminde, Türkiye'nin iktisadi büyümesi küresel likidite bolluğuyla desteklenen iç tüketime dayandı. Bu yeni ekonomik model 2001 yılındaki kriz sonrası oluşturulan liberal kurumların aşındırılmasına, özerkliğini kaybetmesine ve Yürütmenin her alana yayılan gücünün daha da fazla sosyal hayata nüfuz etmesine yol açtı. AB üyeliğinin yıllar boyunca siyasi hayata hakim olmuş klientalist uygulamaları ortadan kaldırması beklenirdi ancak iç dinamiklerin liberal ekonomik ve politik gündemi desteklememesi sonucu bu ihtimal en azından ertelendi. Sağlıklı bir piyasa ekonomisinin üzerine oturduğu hukuk devleti ve kamu hizmetlerinin tedarikindeki partiler üstü yaklaşım, siyasi hedeflerin kurbanı oldu. Popülist politikalar ise siyasi iktidarın seçmen tabanını yaygınlaştırıp, 


\section{BUJSS}

9/1 (2016), 173-186

konsolide etti. Bu çalışmayla Türkiye'de siyaset yapımının bu yeni süreçlerini ve dinamiklerini irdelemeyi hedefliyoruz.

Anahtar Kelimeler: rant arama, neo-popülizm, AB, Türkiye, AKP

\section{Introduction}

Turkey was granted the status of EU candidate after Helsinki Summit in 1999 and formal accession talks started in 2004. Initial enthusiasm for an eventual EU membership was fuelled by the anticipation that the country would move towards European standards. The reward of an eventual accession convinced different segments of the population that a fundamental transformation of the economy and society brought positive payoffs for all. An economic reform program that was being implemented after 2001 crisis was accompanied by EU reforms required for accession talks and finally membership to the Union. The main logic of the program was to lay out the basis for rule of law and restrict arbitrary uses of power by ruling groups. As a full package, the engine of growth of the economy would be market driven initiatives rather than centrally distributed rents and political patronage networks. Independent institutions were created to enhance competition, to regulate markets and to stand against short-term opportunism of politicians. Public debates were centered on economic development, democratization and the possibility of further integration with the global economic system.

A decade later, declining growth rates, increased political polarization at the domestic front and problems with EU as well as hostility with regional powers at international arena dominate Turkey's agenda. Ruling party increasingly adopts a polarizing language against its domestic opponents while at the same time customizes the nationalist rhetoric of the old regime to include some Islamist flavor. While political discourse increasingly looks like previous decades' methods of mobilizing popular support so is the economic model reverting back to its factory settings. A decade long struggle to orient Turkish economy and democracy to Western standards is faltering while distribution of favors to cronies, patronage networks and clientalism is re-emerging. As in many cases in populist governments, ruling party's spokesmen cling to an anti-elitist rhetoric claiming that they have wiped out a parasitic group of cronies in order to bring the riches to poor masses but a new embedded elite is also emerging to take its share.

For the ordinary people, AKP rule did not go without benefits as can be deduced from the massive support for the ruling party election after election. The government skillfully used specific redistributive policies to establish itself as the representative of ordinary people. After a daunting crisis in 2001, AKP government provided a financial boost for many and the economic growth reached record high levels for almost a decade. Even though this economic accomplishment was created while fiscal discipline was strictly maintained, 


\section{BUJSS}

9/1 (2016), 173-186

populist elements in the policy conduct became more prevalent as time went by. A neo-populist Ankara agenda has replaced hopes for European integration with its reckless economic policies as well as a polarizing political discourse.

\section{Populism}

We will use the term populism both with its political context meaning a strong emotional connection with the charismatic leader and neglect of all other intermediate independent institutions, a dichotomist perception of the world as well as the economic content meaning of an unsustainable system of favors to the masses for political support. From the economic point of view, populist policies will ultimately hurt a significant part of the society in the long run even though in the short term it seems to be favoring them (Dornbush \& Edwards, 1991: 7-13). In economic populism, growth and income redistribution is emphasized at the expense of the risk of inflation, deficit financing and economic turmoil. An expansionary economic period is followed by sudden collapses as changes in global conditions are realized and stabilization programs will follow to the detriment of especially low income groups in the society. Most of the time, the measures taken by the politicians to buy off voters ends up in a situation that makes most of the society worse off than before (Sachs, 1989).

In classical populism, absence of sustainability usually meant fiscal profligacy temporarily funded by borrowing especially from foreign lenders. Economic boom and busts of 1970s after the oil crisis are good examples of such kind of populism. Similarly, right after market liberalization measures were taken in Latin America and Turkey, deficit financing caused populist expansionary periods and collapses. Throughout the post-World War II years populist surges were countered by authoritarian politics bringing back stabilization programs.

In the neoliberal era, at first it was thought that the decline of workers unions and urban masses as opposed to the increasing power of financial and industrial groups would bring populism in a state of permanent decline (Kauffman \& Stallings, 1991). With the ascendancy of liberal policies, alternative programs would have lost their chance of survival. However, after 1990s a unique amalgam of neoliberal and neopopulist policies was implemented rather successfully in Latin America (Weyland, 1996) and in Turkey. The fact that purely market oriented policies seriously damaged large sections of the population required compensatory mechanisms for the losers of the new system from a political point of view. Under these circumstances market reforms and populism, which was once considered incompatible, ended up complementing each other.

The re-emergence of a new version of populism could be witnessed as those policies were readjusted to partially meet requirements of relatively market friendly governments as in the case of Argentina's Menem and Peru's Fujimori (Barr, 2009: 40). 


\section{BUJSS}

9/1 (2016), 173-186

Groups that were excluded from previous import substitution economic models were now compensated through various mechanisms while universal market mechanisms established their predominance. At almost around the same times, the rise of right-wing populism could also be attributed to this anti-political atmosphere and the disappearance of powerful alternative programs (Mouffe, 2005). Political power was concentrated at the apex of the state leaving little discretionary power to intermediate levels and opposition to reforms could be swiftly overcome.

On the other hand, constraints for clientalist policies and patronage networks need to be taken into account in the form of market requirements. But the claim that ruling parties abandon populist policies once in office and revert back to responsible policies is not completely verified (Weyland, 2003). On the contrary, a compromise is established between two seemingly contradicting forces at least for some time to come. This is the period in which a resurgence of populist policies can be witnessed in modern times (Roberts, 2010; Levitsky \& Loxton, 2013). More recently, populist policies have dominated especially the countries with large resource riches as in the case of Chavez' Venezuela (Parenti, 2005; French, 2010). Even though those countries need not be making deficit financing, the volatility of commodity prices require that government should not pursue fiscally irresponsible policies during boom times as it would be much harder to reverse course during bust times.

Rhetorically populism uses the distinction between "us" and "them" where the former refers to impoverished masses exploited by the rich and elitist latter (Laclau, 2005). From this point of view there is an unbridgeable gap between the exploiting elites and ordinary people while the populist leader or political current is representing the oppressed against the privileged. The binary logic of the populist discourse (Hawkins, 2009) here prevails as the good and innocent masses against evil ruling classes. It cannot be attributed to a certain political movement nor it needs to belong to certain persons or parties but they are rather forms of identification and ways of making politics (Panizza, 2005). Consequently both left wing political parties and right wing movements utilized populist forms of political discourse. Both in previous cases in Latin America and in our current subject Turkey, the populist minded policy makers emerged as a reaction to corrupt elitist systems. Nevertheless, they themselves finally succumbed to the allure of power and form a new elite to exploit the riches in line with the "iron law of oligarchy" (Michels, 1962). The populist vision purposefully disregards that a similar relation is immediately established between the new ruling elites and the rest of the society.

A strong and charismatic leader is required for the masses to associate with this holy struggle against the corrupt elite. The leader presents itself as an outsider to the established elite (Barr, 2009) relying on the 


\section{BUJSS}

9/1 (2016), 173-186

power of the people unlike previous politicians who represent parasitic interest groups. His political organization lacks key values but there is an executive branch mobilized to support the leader in its struggle against the elitist forces (Taggart, 2000), making the whole hierarchy an instrument of leader's will. The holy struggle, in the name of the people, for the people, needs unquestioning obedience to the leader's will. In an environment where power is concentrated in the hands of a single person and the rest is subordinated to his will, autonomous centers of power and political deliberation disappear. The leader is gradually surrounded by loyal opportunists seeking to extract private benefits in exchange for their unquestioning support. This vision works to the detriment of institutionalized political parties, including the leader's own party. As s/he is considered to be the embodiment of national will, intermediary institutions are redundant at best, obstacles to realization of popular goals most of the time. Populist waves open the road to a plebiscitarian democracy (Mayorga, 2006) which is apparently in contradiction with liberal values and institutions.

Even though there is a tendency to associate populist policies as being against the interest of the rich elite (Acemoğlu, Egorov, \& Sonin, 2013) there are other elite groups who benefit from this political agenda. Populism cannot basically be explained as the political mobilization of poor segments of the society against monolithic entrenched elite. On the contrary populist politics serve well to their own embedded economic supporters in return for their loyalty. On many occasions benefits of redistributive policies were eventually captured by specific interest groups (Alesina, 1989). Even a majority of the voters may prefer to give the leader a free hand in redistributive policies, accepting that political rents will accrue in the absence of liberal institutions. Destruction of checks and balances and a purely majoritarian democratic system may temporarily be preferable for significant groups in the society (Acemoğlu, Robinson, \& Torvik, 2013). This explains why populist policies persist and are resurrected despite occasional political and economic collapses that they cause.

\section{Populism in Turkey: From the Past to the Present}

Populist politics is not a novelty (Sunar, 1990; Yeldan, Boratav, \& Köse, 2000) for Turkey. In its classical fashion, populism became a mainstream form of policy making especially after multi-party elections started and Demokrat Parti (DP) took over in the 1950s (Sunar, 1985). During the interwar years, a vast majority of the population felt alienated from politics and considered the single party rule to be the institutionalized form of elitist interests. Once DP took over in 1950s, massive subsidies to agricultural sector and relative improvement in ordinary peasants' lives secured consecutive electoral wins for the ruling party. In the second half of the 20th century, populist policies followed the classical trend where unsustainable economic expansion periods were followed by sudden contractions to make a majority of the population worse off. 


\section{BUJSS}

9/1 (2016), 173-186

Both from the right and from the left, politicians resorted to populist themes in an environment of intense political competition. The economic troubles, failure to deal with poverty and income inequality were natural consequences and the blame was put on the entrenched interest groups who were defending their own good at the expense of the society.

Macroeconomic instability lasted much longer in Turkey when compared to Latin America while chronic inflation and sustainability of fiscal balances became major issues throughout 1980s and 1990s. The reform program that was implemented after 2001 crisis was in fact a response to this vicious cycle of booms and busts aiming to eliminate populist cycles (Alper \& Öniş, 2003). The so called "Transition to a Strong Economy Program" was designed to forestall any politically motivated threats to economic stability and establish the framework for a reformist program taking the Maastricht Criteria as its guide (Yeşilada, 2002; Togan, 2004). The program was not only about bringing down budget deficits, dealing with the troubled banking system and reining in rampant inflation. The main motive of the program was establishing the liberal institutions that would lock-in a permanent market based economic system (Öniş, 2009). The politicians would lack the means to respond to populist appeals that would hurt the whole society eventually.

The coalition government that initiated the reform program was brought down by popular vote in 2002, while the cost of structural adjustment program urged a significant segment of the population to vote for the newly found AKP in the elections. AKP entered the political arena as an outsider force criticizing the drawbacks of current regime in terms of delivering the expectations of the masses.

Islamist movement had already positioned itself as a peripheral force but one that had a deep echo within the society and one that will struggle against the cosmopolitan and corrupted elite in the name of the people. Even though AKP refused to assume the Islamist vision of its predecessors and claimed to be a conservative democratic party (Özbudun, 2006; Ahmadov, 2008), the appeal of the party came from its claim to be the voice of those who have been neglected so far. However, at its early stages, the ruling party's approach to politics was a reformist globalist and pro-EU agenda (Öniş, 2007) rather than an antagonistic attitude with the rest of society. These policies went in parallel with a vocal support for Turkey's membership to EU and acquisition of its criteria. Fiscal balances were restored and economic growth resumed as investors' and consumers' confidence for future rebounded. 


\section{BUJSS}

9/1 (2016), 173-186

Table-1: Growth Rates and Budget Balance

\begin{tabular}{|c|c|c|}
\hline Years & GDP Growth Rate \% & EU Defined Budget Balance / GDP \% \\
\hline 2003 & 5.3 & -9.0 \\
\hline 2004 & 9.4 & -4.5 \\
\hline 2005 & 8.4 & -0.6 \\
\hline 2006 & 6.9 & -0.8 \\
\hline 2007 & 4.7 & -1.0 \\
\hline 2008 & 0.7 & -2.2 \\
\hline 2009 & -4.8 & -6.7 \\
\hline 2010 & 9.2 & -3.5 \\
\hline 2011 & 8.8 & -2.4 \\
\hline 2012 & 2.1 & -2.3 \\
\hline 2013 & 4.1 & -1.2 \\
\hline 2014 & 2.9 & -1.3 \\
\hline
\end{tabular}

Source: Worldbank, Ministry of Treasury

Overall, the conduct of fiscal policy was highly responsible while consolidated public debt / GDP ratios were brought down from a level of $74 \%$ in 2002 to $36 \%$ in 2014 . This implies that a classical form of populist overspending from state coffers is not valid in the case of AKP. The government accepted fiscal discipline as the anchor of economic stability and clung to it all along the way. In the meantime, AKP's success in its early years owed much to the compensatory programs for the impoverished masses such as free health service, food and coal aid for the poor provided by local administrations. Those aid programs alleviated the burden on ordinary people but were not well organized and were conducted not directly as welfare programs but rather as clientalist practices, specifically targeted to reward certain popular groups that support AKP. However, they do not necessarily imply an unsustainable economic policy that would work to the detriment of the society in the long run.

If we accept the economic definition of populism to cling on to policies that are not sustainable in the long run and policies that bring short term relief even if it was to hurt the majority of the population in the short run, AKP-type populism depended on continuous and explosive expansion of domestic demand. 
On the positive side, the government successfully controlled rampant budget deficit even though the reform package started to be implemented during previous coalition government. While fiscal austerity resumed investor confidence and interest rates fell, private consumption and investment surged to compensate for the lagging demand. The inflow of funds triggered a massive surge in domestic credit.

Table 2- Domestic Credit Ratios

\begin{tabular}{|c|c|}
\hline & $\begin{array}{l}\text { Credit to Non-Financial } \\
\text { Sector / GDP }\end{array}$ \\
\hline 2003 & $19 \%$ \\
\hline 2004 & $21 \%$ \\
\hline 2005 & $26 \%$ \\
\hline 2006 & $32 \%$ \\
\hline 2007 & $37 \%$ \\
\hline 2008 & $43 \%$ \\
\hline 2009 & $44 \%$ \\
\hline 2010 & $50 \%$ \\
\hline 2011 & $56 \%$ \\
\hline 2012 & $59 \%$ \\
\hline 2013 & $70 \%$ \\
\hline 2014 & $74 \%$ \\
\hline
\end{tabular}

Source: Bank of International Settlements

Turkey had a chronic inflation problem since the beginning of 1980 s and real interest rates were consequently high to compensate for devaluation risk. Once inflation was tamed during AKP rule, falling risk premiums and real interest rates laid the basis for an expansion in consumer credits. Moreover, better fiscal management reduced government's demand from the pool of savings. The consumers that held back their purchases because of prohibitively high interest rates and uncertainty in the previous years now started buying cars, domestic appliances and electronic equipment but the biggest hike was on demand for houses.

The hyperactivity in construction sector brought multi-faceted benefits for the ruling party. The availability of mortgage credits and lower real interest rates allowed ordinary Turkish households to finally afford a decent home. 


\section{BUJSS}

9/1 (2016), 173-186

The labor-intensive nature of construction sector also allowed for a reduction in unemployment rate, especially for unqualified workers who had no employment opportunity other than physical labor. While home ownership affected middle income groups, lower socio-economic status groups were positively influenced by the increase in labor demand. Finally, the vertical linkages that the sector has with other industries created a multiplier effect in the whole economy, giving a boost to growth rates. Iron and steel factories, cement plants, glass industry all benefited from a rise in demand from the construction.

Neither the construction boom, nor soaring demand for non-perishable goods are by themselves indicators of an unsustainable path of growth but a steady decline in national savings raised concerns. On the one hand, the government was successful in fiscal management constraining extravagant expenditures while on the other did not worry about a slump in savings accompanied by a huge borrowing and spending spree. The most prominent aspect of populist policies in Turkey thus became leaving a private sector-led spending boom unattended. National savings figures and current account deficits displays extent of the problem as an already savings gap continues to deteriorate:

Table-3 National Savings and Current Account Balance

\begin{tabular}{|c|c|c|}
\hline & Gross Savings / GDP \% & $\begin{array}{l}\text { Current Account Balance } \\
\text { GDP } \%\end{array}$ \\
\hline 2000 & 17.8 & -3.7 \\
\hline 2001 & 19.2 & 1.9 \\
\hline 2002 & 19.2 & -0.3 \\
\hline 2003 & 16.6 & -2.5 \\
\hline 2004 & 16.4 & -3.6 \\
\hline 2005 & 16.5 & -4.4 \\
\hline 2006 & 17.1 & -6.0 \\
\hline 2007 & 15.9 & -5.8 \\
\hline 2008 & 17.3 & -5.5 \\
\hline 2009 & 13.8 & -2.0 \\
\hline 2010 & 14.0 & -6.2 \\
\hline 2011 & 14.0 & -9.7 \\
\hline 2012 & 14.9 & -6.1 \\
\hline 2013 & 15.0 & -7.9 \\
\hline 2014 & 14.1 & -5.7 \\
\hline
\end{tabular}

Source: Worldbank 


\section{BUJSS}

9/1 (2016), 173-186

While deterioration in savings and current account balance was witnessed, independent institutions that were established after 2001 crisis in line with EU standards were systematically eroded. Government auction law, regulatory bodies, supervisory entities all became instruments of political wrestling and subordinated to the will of political leader. Accordingly, all independent institutions were instruments of tutelage over the popular will Government's assault on liberal institutions was based on a classical popular discourse of "us" represented by the elected offices against "them", the institutions that are the tools of elitist groups. Those elite groups were naturally in cooperation with foreign agents and cosmopolitan centers and were conspiring against the national will.

Erdoğan's and his loyalists' latest assault on Central Bank is the perfect example of this trend. Growth rates in Turkish economy dwindled after 2012 while the expansion in domestic demand slowed down and export markets stagnated both as a result of European crisis and armed conflict in the Middle East. The technocratic minded economy administration that was at liberty to implement their program for almost a decade came under pressure from the government to ease monetary policy and unleash domestic demand. However, inflation targets were already being missed and the credibility of the monetary authority could be compromised if a looser policy were implemented. Nevertheless, for the populist axis of ruling party reduction on interest rates and a boost in demand for construction sector was the primary objective.

In the last years, the populist assault was shifted from classical opposition to independent institutions that were established during the reform program and checks and balances of the government. Prime Minister and later President Erdoğan engaged in a campaign to present judiciary mechanisms as the last vestiges of tutelage on popular will. As they had been under the control of elite groups and exercised a power not granted by the people, Erdoğan complained to his constituents that judiciary should be controlled by "national will" and took necessary measures to subordinate it.

AKP's reversal of "auction law" is a similar reversal of reformist policies and a deterioration of econo-political environment (Nar, 2015). After 2001 crisis, Derviş reforms also aimed to create an auction system in line with European standards. The main purpose of those reforms was to create a transparent and competitive system to minimize the effect of political meddling and rent-seeking behavior. Nevertheless, this reform also implied that the ruling parties would be deprived of one of the most appropriate tools of political patronage. There are mega-projects undertaken by the government and boosted with pride and bombast as the monuments of a "new Turkey" in the making. The most prominent of those are the gigantic airport that is been constructed on the north of Istanbul, a third bridge to cross the Bosphorus, Istanbul-İzmir highway, high-speed train railways, various airports in all over the country, nuclear plants and a multitude of 


\section{BUJSS}

9/1 (2016), 173-186

energy plants and etc. A major part of those projects are undertaken by a bunch of groups that are renowned for their loyalty to Erdoğan. Those groups are also owners of TV channels, newspapers that are staunch supporters of Erdoğan himself and consistently propagate views that elite groups are conspiring against the leader who is himself representing the popular will.

The major effect of those changes was to concede an arbitrary discretionary power to the government in the process. The auctions would be set up such that favored groups would outbid other contenders and the government would assist them by making the necessary amendments on the conditions of the tender. In an effort to help those embedded business interests, the government also guaranteed payments to third parties on those transactions. In return, those groups provided donations to AKP controlled foundations, whose main duty is do charity work according to undertake the gigantic task of targeted redistributive role in return for popular support in the elections. This extremely well designed clientalist mechanism performed well election after election as impoverished masses voted overwhelmingly for the ruling party.

\section{Conclusion}

We claim that AKP's initial preference for a EU centered reform program is being transformed into a populist economic policy throughout the years and we can witness a similar shift in the form of their communication to their constituents. The initial program's targets to establish independent institutions, focus on long term sustainable growth and reduction of clientalist policies contradicts contemporary trends. AKP government reversed many reform packages such as auction law, meddled with independent institutions like the Central Bank and subordinated regulatory institutions. Politics now control many aspects of the economy and the presence of autonomous institutions is considered as a violation of the democratic principles.

While Erdoğan made his bid to consolidate power while his supporters attacked all forms of intermediate institutions as usurpers of "national will". Even an independent judiciary was labeled as the instrument of the political elite trying to stand against the fulfillment of nation's interest embodied in the leader.

Constitutional amendments and the calls for an a-la-turca Presidential system are all reflections of this mental framework. In order to mobilize the society behind the mission, AKP leadership gave a boost to credit based economic expansion program that could be sustained thanks to an unprecedented easy money policy in the Western World. When reformist minded policy makers and technocrats realized the unsustainability of this expansion and tried to curb extravaganzas of the system they became targets to the wrath of Erdoğan himself. 


\section{BUJSS}

9/1 (2016), 173-186

Although the new form of neo-populism differs in some aspects from its predecessor classical populism, in terms of sustainability it suffers similar weaknesses. Once the extraordinary monetary policies which have been sustained for long periods are abandoned, markets will be harsher on those governments that destroy the infrastructure of a healthy market economy. The politicians relying on the dichotomy between "us" and "them" have so far been successful in convincing the majority to their programs but that could only be achieved when accompanied by economic growth. Pure rhetoric will be increasingly unsatisfactory for the impoverished while economic stagnation continues. Neo-populism in Turkish case met the demands of large segments of the population and was a reaction to economic failures and exclusive policies. Nevertheless, the success of this program seem to reach its limits as growth rates are falling and the fragmented conception of the society is increasingly becoming void. That is why neo-populism's war against the clock may be prolonged depending on global conditions but doomed to fail in the long run. Yet, this does not deny the fact that Turkey continues to need redistributive programs as income and wealth inequality continue to be big problems still. Only this should not be achieved at the cost of destroying rule of law, independent institutions and the infrastructure for a sustained healthy economy. 


\section{BUJSS}

9/1 (2016), 173-186

\section{REFERENCES}

Acemoglu, D., Egorov, G., \& Sonin, K. (2011). A Political Theory of Populism, no. w17306. National Bureau of Economic Research.

Acemoğlu, D., Robinson, J. A., \& Torvik, R. (2013). Why do Voters Dismantle Checks and Balances? Review of Economic Studies, 80(3), 845-875.

Ahmadov, R. (2008). Counter Transformations in the Center and Periphery of the Turkish Society and the Rise of the Justice and Development Party. Alternatives, 7(2-3), 15-36.

Alesina, A. (1989). The Political Economy of Macroeconomic Stabilization: Myths and Reality. V. Tanzi, \& K. Chu eds, Income Distribution and High Quality Growth. Cambridge: MIT Press.

Alper, E. C., \& Öniş, Z. (2003). Financial Globalization, the Democratic Deficit and Recurrent Crisis in Emerging Markets. Emerging Markets Finance and Trade, 39(3), 5-26.

Barr, R. R. (2009). Populists, Outsiders and Anti-Establishment Politics. Party Politics, 15 (1), .29-48.

Dornbush, R., \& Edwards, S. (1991). The Macroeconomics of Populism in Latin America. Chicago: University of Chicago Press.

French, J. D. (2010). Understanding the Politics of Latin America's Plural Lefts (Chavez/Lula): Social Democracy, Populism and Convergence on the Path to a Post-Neoliberal World. Third World Quarterly, 30 (2), 349-370.

Hawkins, K. A. (2009). Is Chavez Populist? Measuring Populist Discourse in Comparative Perspective. Comparative Political Studies, 1040-1067.

Kauffman, R. R., \& Stallings, B. (1991). The Political Economy of Latin American Populism. R.

Dornbusch, \& S. Edwards eds, The Macroeconomics of Populism in Latin America, Chicago: University of Chicago Press, 15-43.

Laclau, E. (2005). On Populist Reason. London: Verso Publishing.

Levitsky, S., \& Loxton, J. (2013). Populism and Competitive Authoritarianism in the Andes. Democratization, 1, 107-136.

Mayorga, R. A. (2006). Outsiders and Neopopulism: The Road to Plebiscitary Democracy. S. Mainwaring , A. M. Bejarano, \& E. P. Leongomez eds., The Crisis of Democratic Representation in the Andes, Standford: Stanford University Press, 132-170

Michels, R. (1962). Political Parties: A Sociological Study of the Oligarchical Tendencies of Modern Democracies. New York: Collier Books. 


\section{BUJSS}

9/1 (2016), 173-186

Mouffe, C. (2005). The End of Politics and the Challenge of Right Wing Populism. F. Panizza eds., Populism and the Mirror of Democracy. London: Verso, pp. 50-71

Nar, M. (2015). The Committed Changes within Public Procurement Law in Turkey (2003-2014): A Conceptual Analysis. International Business of Business and Social Research, 5(2), 1-20.

Öniş, Z. (2007). Conservative Globalist versus Defensive Nationalists: Political Parties and Paradoxes of Europeanization in Turkey. Journal of Southern Europe and Balkans, 9(3), 247-261.

Öniş, Z. (2009). Beyond the 2001 Financial Crisis: The Political Economy of the New Phase of Neo-Liberal Restructuring in Turkey. Review of International Political Economy, 16(3), 409-432.

Özbudun, E. (2006). From Political Islam to Conservative Democracy. South European Society and Politics, 11(3-4), 543-557.

Panizza, F. (2005). Populism and the Mirror of Democracy. London: Verso Publishing.

Parenti, C.( 2005). Hugo Chavez and Petro Populism. The Nation, 24.

Roberts, K. M. (2010). Latin America's Populist Revival. SAIS Review, 27(1), 3-15.

Sachs, J. (1989). Social Conflict and Populist Policies in Latin America. NBER Working Paper, w2897

Sunar, İ. (1985). Demokrat Parti ve Popülizm. Cumhuriyet Dönemi Türkiye Ansiklopedisi (8), 2083-2084.

Sunar, İ. (1990). Populism and Patronage: Democrat Party and Its Legacy. Il Politico, 55(4), 747-757.

Taggart, P. (2000). Populism. Buckingham: Open University Press.

Togan, S.(2004). Turkey: Towards EU Accession. The World Economy, 27(7), 1013-1045.

Weyland, K. (1996). Neopopulism and Neoliberalism in Latin America: Unexpected Affinities. Studies in Comparative International Development, 31(3), 3-31.

Weyland, K. (2003). Neopopulism and Neoliberalism in Latin America: How Much Affinity. Third World Quarterly, 24(6), 1095-1115.

Yeldan, E., Boratav, K., \& Köse, A. H. (2000). Globalization, Distribution and Social Policy: 1980-1998. New York: Center for Economic Policy Analysis.

Yeşilada, B. A. (2002). Turkey's Candidacy for EU Membership. Middle East Journal, 56(1), 94-111. 